\title{
Social Security Systems in the CARICOM Member States
}

\author{
Agnes Matits* \\ Hungary \\ *Corresponding Author: Agnes Matits, Hungary

\begin{abstract}
This paper was prepared by Agnes Matits, a pension actuary in Hungary. It is based on a report which was part of a project supported by the European Union. The purpose of this report was to detect the features of social security systems in the region in order to find some possible steps towards harmonization of social security systems within the CARICOM, the community of 15 English-speaking countries in the Carribean region. The paper gives a summary of main characteristics of public pension schemes in the CARICOM member states giving a picture of the similarities and differences among them. It shows a measure on the different risk factors of public pension schemes and finally some recommendations are framed in order to help the harmonization processes.
\end{abstract}

\section{INTRODUCTION}

The pensions, pension systems are part of common talk. It is known that the changing social circumstances, the challenges of the demography, the new types of employments have raised more and more questions on existing pension systems. Many comments and suggestions could be sound. But people do not know enough neither on the systems themselves nor the real problems. This article is going to trace the main features of social security pension systems and their problems in an exotic example. It shows in the actualities of the social security systems in the fifteen Member States of the Caribbean Community (CARICOM)

CARICOM Member States have well-established Social Security systems of wide range of size. The scope of services offered by Social Security organisations in the more developed states and the less developed states are similar. They provide various types of benefits, pensions and grants. Protections for dependants are also provided. Most national systems offer similar benefit package for employed and self-employed persons. The effective participation of people is different. In some countries less than 50 percent of the employed persons are contributing to the national insurance system, and coverage of self-employed persons is generally low. The systems have their own governance and administrative structures, contribution and benefit rules. There are major differences in these rules. In this report we are going to detect these differences and their effects on the possible harmonization. According to a study of the World Bank ${ }^{1}$, there are "common socio-economic characteristics that frame the pension policy needs. Challenges and options in the Caribbean include: (i) an ongoing population aging process that varies substantially between countries; (ii) high levels of emigration and immigration both within the Caribbean and from the Caribbean to countries outside the region; (iii) the prevalence of small island economies, labour mobility and the need for portability of pension rights; (iv) substantial volatility arising from economic concentration and climatic conditions, including hurricanes and (v) limited evidence on elderly poverty levels in the Caribbean suggesting that although the incidence of poverty among the elderly is in some cases smaller than among the younger population, the elderly are still likely to be more vulnerable than those of working age." The leaders of the region must consider these statements.

The differences in national legislation can cause difficulties in worker mobility across the CARICOM Member States. The lack of harmonization between national legislation creates difficulties for workers' mobility across CARICOM. While harmonisation is a required measure for the Free Movement Regime ${ }^{2}$ many barriers still exist (e.g legislative and administrative processes).

\footnotetext{
${ }^{1}$ Strengthening Caribbean Pensions, Report No. 47673-LAC, 2010

${ }^{2}$ The need for harmonisation was the main message of a seminar hosted by the Caribbean Centre for Money \& Finance held in 2012 on the „Future of the Pension Fund Industry in the Caribbean”. See [29]
} 
Additionally, there is the reluctance of Member States to undertake reform of the Social Security systems .But technical proposals based on professional arguments could be useful for the future considerations.

\section{Social Security Systems in CARicom Member StateS}

\subsection{Scope of Social Security Programs}

A wide range of Social Security programs is available in the Member States People are generally satisfied with the scope of their Social Security programs, even that all agreed that some reforms in Social Security would be advisable.

The scope of Social Security programs might depend on the bearing capacity of the economy society. The differences among the development of the CARICOM Member States might explain if there were differences in the scope of SS programs. But the scope of services offered by Social Security organisations in the more developed states and the less developed states are similar.

Let us see some features of the programs:

Partial pension when a reduced pension is payable if the insured person has not met qualifying conditions for full pension at retirement, exists only in a few CARICOM Member States (Antigua and Barbuda, Grenada, Haiti, Jamaica, Montserrat). Partial pension could help persons who are not fully qualified and could result in reduction of requirement for social assistance programs.

Early pensions or deferred pensions ${ }^{3}$ as products are defined only in a few member states (early pensions exists only in the Bahamas, Dominica and Saint Lucia, deferred pensions are known in the Bahamas and Dominica.) Introducing early or deferred pensions could provide more flexibility for pensionable age.

Unemployment benefits are rare in the region. (Only the Bahamas and Barbados have such a program.) It could be useful to consider introducing this benefit. Even a low level of unemployment benefits could help the effectiveness of (un)employment registration ${ }^{4}$.

Family allowances, when a regular payment is paid by the Social Security system to the families which have more children are also missing. In countries where the decreasing fertility rate is starting to be a problem, the family allowance programs might be a useful incentive.

\subsection{Coverage}

Coverage $^{5}$ - with minor exceptions - is mandatory for all employed persons in all countries. With the exception of Trinidad and Tobago, Social Security covers also self-employed persons.

In several countries self-employed persons are excluded from work injury benefits (Bahamas, Barbados, Dominica, Grenada, Guyana, St Kitts and Nevis, St Lucia, and St Vincent and the Grenadines) and from maternity benefits (Guyana) or unemployment benefits (Barbados).

Most schemes offer voluntary insurance (except Antigua and Barbuda) which allow for persons who wish to enhance their benefits, to do so.

Some comments on the coverage of Social Security programs:

If the labour force participation rate is low, or the share of contributors in the employed population is low or decreasing, the coverage which is focused on the employed persons could be unsatisfactory in the society. There are some CARICOM member states where the share of insured persons is less, than 70 percentage of employed population ${ }^{6}$ (e.g. Jamaica, Guyana). Meanwhile, the share of formally employed persons within the population $15+$ is less than $65 \%$ in almost all the countries. It means that a big part of the population has not been covered in practice.

\footnotetext{
${ }^{3}$ In case of early pension, the pension is reduced if the retiring person is younger than the normal retirement age. In case of deferred pensions bonuses are paid in pensions when he is older than the normal retirement age.

${ }^{4}$ Unemployment benefits could be paid according to contributions, presumably and only for a limited time.

${ }^{5}$ The word "Coverage" could be used in two meanings: first when we are interested of the groups of persons who are mandated or allowed to join to the Social Insurance programs; the other meaning is when we are interested about the share of persons in a group who are really supplied by the services of Social Security system..

${ }^{6}$ See also [7]
} 
If the system is not good enough to induce self-employed persons to register or there is no efficient control to follow their contributions, the coverage of self-employed persons will be unsatisfactory ${ }^{7}$.

Voluntary coverage within the Social Security system should be more than simply allowing persons to continue contributing. More and more people out of the formal economy are never mandated to contribute. In order to protect also this part of the society, social insurance might offer possibilities for more people to contribute voluntarily. Or more people (e.g. household workers, people working in family business, casual workers) might be offered the opportunity or mandated to register in the Social Security system.

There are some differences in the coverage of public and private sector workers. It makes the systems more difficult to understand and may hinder the harmonization processes It would be useful to eliminate any distinction between private and public sector workers.

\subsection{Source of Social Security Funds}

The main source of Social Security financial programs is contributions. In all countries, contributions are shared by employers and employees. While the scope of Social Security programs is similar, the contribution rates are very different in the Member States (see Chart 1).

The contributions cover the old-age, disability and survivor pensions and - in most cases - also the sickness and maternity benefits.

The contributions are not the only possible resource for benefits.

Theoretically any kind of deficit of Social Security funds or the non-contributory programs could be covered by the surplus funds or by the State budget. In fact, in most CARICOM Member States the Social Security funds have not had any deficit so far. But the non-contributory programs are generally also covered by contributions and not by the state budget or by the reserves.

In most Member States there is no need to use the surplus funds to finance the benefits at this moment. But we have to keep in mind that this sound status will not last forever. There are some countries where deficits have occurred, but the majority of the Member States still have some time to change the current contribution rates or to consume the reserves.

According to a report of the UN Population Division ${ }^{8}$ the old age dependency ratio in the region by the middle of this century will be more than three times the current level. (The average of old age dependency ratio ${ }^{9}$ in the region is 11 in 2010, 37 in 2050). As a consequence, the current level of contributions will not be enough to cover the benefits. The first year of cash flow deficit is projected before 2020 in 7 countries: Antigua and Barbuda, The Bahamas, Belize, Dominica, Guyana (even now), Jamaica, and St. Vincent and the Grenadines). Saint Lucia, St. Kitts and Nevis and Grenada are in the best position: with the current accumulation positions the projected date of run-down of their reserves is 2050 or later.

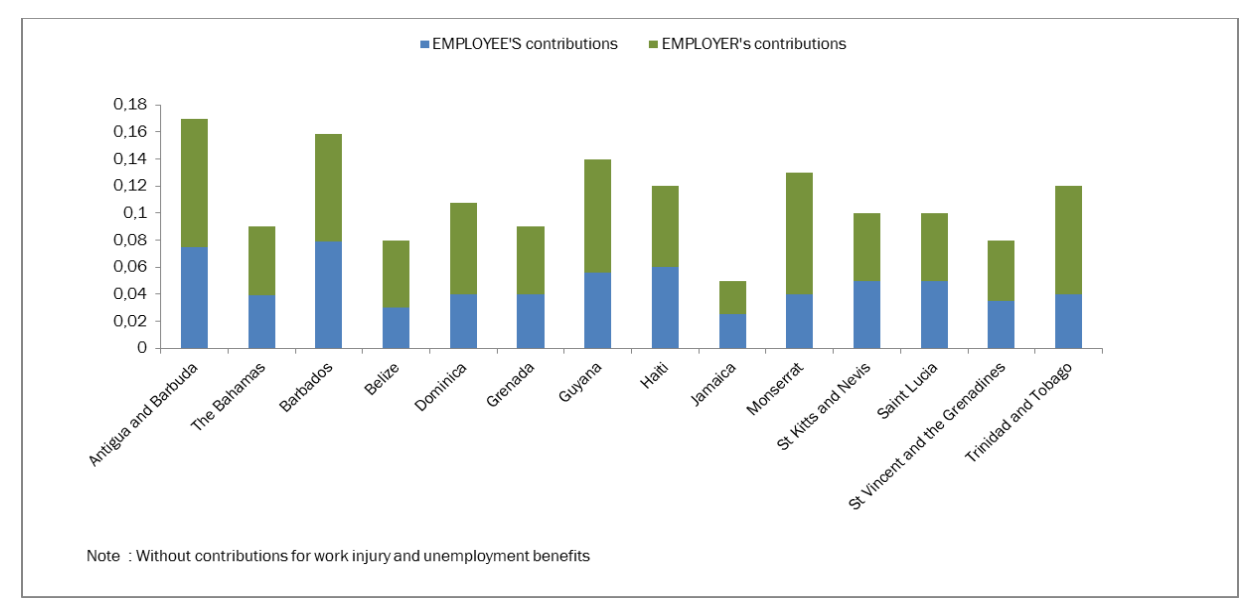

Chart1. Contribution Rates in CARICOM Member States (2014)

\footnotetext{
${ }^{7}$ We have not had information on the contributory income of self -employed persons.

${ }^{8}$ See $[30]$

${ }^{9}$ Old age dependency ratio (Population 15-64 to the population 65+) shows how many active people should pay for one pension.
} 
Some Member States are considering changing the contribution rates. Perhaps it is reflected in the diverse responses to the question on contributions ${ }^{10}$. Most respondents agreed that benefits should be strictly dependent on contributions; however, the present situation is not like that.

At first sight, there are no good arguments for the differences among the contribution rates in the Member States. If the benefits are different in the different countries, the differences in contributions are acceptable. But there is no real connection between the level of contributions and the level of services.

Let us have an example! We calculated the sum of initial pensions in all the member states in the same pre-conditions. Let us suppose that the claimant is at age $66^{11}$ and had a record of pensionable monthly earning (a flat sum) of equal to US\$500. He contributed 1500 weeks.

We can calculate the monthly contribution (we suppose that the same contribution rate was valid all over his career) and the pension promises in all the countries according to their national regulation for pensions. Table 1 show the results of the calculations.

Table1. Replacement Rate of Initial Pensions as a function of Contribution Rates in the CARICOM Member States

\begin{tabular}{|c|c|c|c|c|c|c|c|c|c|c|c|c|c|c|}
\hline & Jamaica & $\begin{array}{l}\text { St Vincent } \\
\text { and the } \\
\text { Grenadines }\end{array}$ & Grenada & Monserrat & $\begin{array}{c}\text { The } \\
\text { Bahamas }\end{array}$ & $\begin{array}{c}\text { Antigua } \\
\text { and } \\
\text { Barbuda }\end{array}$ & $\begin{array}{c}\text { St Kitts } \\
\text { and Nevis }\end{array}$ & $\begin{array}{l}\text { Saint } \\
\text { Lucia }\end{array}$ & Dominica & $\begin{array}{l}\text { Trinidad } \\
\text { and } \\
\text { Tobago }\end{array}$ & Belize & Haiti & Guyana & Barbados \\
\hline \begin{tabular}{|c|}
$\begin{array}{c}\text { Rate of total } \\
\text { contributions }\end{array}$ \\
\end{tabular} & $5 \%$ & $8 \%$ & $9 \%$ & $9 \%$ & $9 \%$ & $10 \%$ & $10 \%$ & $10 \%$ & $11 \%$ & $11,3 \%$ & $12 \%$ & $12 \%$ & $14 \%$ & $16 \%$ \\
\hline $\begin{array}{c}\text { Replacement } \\
\text { ratio at } \\
\text { retirement }\end{array}$ & $59,9 \%$ & $50,0 \%$ & $50,0 \%$ & $46,0 \%$ & $51,5 \%$ & $45,0 \%$ & $55,0 \%$ & $59,5 \%$ & $60,0 \%$ & $94,5 \%$ & $55,0 \%$ & $33,3 \%$ & $55,0 \%$ & $60,00 \%$ \\
\hline
\end{tabular}

Source: Author's calculations

We can see that the pension promises are not really connected to the contributions required. For the same level of contribution one can get higher or lower level of pension ${ }^{12}$ or the same level of pension could belong to different level of contributions.

The differences among the contribution rates and the lack of direct connection between the contributions paid and the pension promises could be an obstacle in the harmonization process.

Most of the contributions cover different services and the contributions are generally not separated according to the types of benefits. ${ }^{13}$ We can approach this problem also from the point of view of the CASS. Concerning the more effective harmonization it would be desirable if the contributions for services affected by CASS would be separated in all Member States. As a second step, the contribution rates dedicated for pensions (old-age, disability and survivors) might be coordinated in the region.

\section{PENSION SYSTEM DESIGN}

\subsection{Elements of Pension Systems}

Relating to the long-term effects of pension systems, the history of Social Security is not really long in the region. The problems of Member States could be different from the problems of matured Social Security systems. English-speaking CARICOM Member States, with the exception of Jamaica, share the same kind of defined-benefit structure for their Social Security schemes. Within the public pillar a number of design characteristics are similar to most CARIICOM member state schemes, including higher accrual rates for the initial 10-15 years, generally similar (but not the same) vesting periods, caps on covered wages, and benefit adjustments subject to parliamentary approval. The private or occupational pensions have no general significance in the region. The necessity of private arrangements supplementary to the public schemes is commonly discussed, but of course mainly among people who have higher disposable incomes.

\footnotetext{
${ }^{10}$ Only about 60 percent of the respondents said that level of contribution rate is good or satisfactory in their country.

11 In case of the Bahamas and Dominica the deferral bonuses increase the initial pension.

${ }^{12}$ The level of pension is measured by a calculated replacement ratio: The calculated sum of initial pension as a percentage of pensionable earning

${ }^{13}$ The contributions for pension are separated in Antigua and Barbuda.
} 
The subject of non-public schemes is out of scope of this project still we have some comments to share on this topic:

As no kind of public system is able to provide a satisfactory pension for all citizens, multi-pillar pension systems would be desirable. The communication supportive of private pensions is an important task of all the governments. The regulation should also support the regular savings. (Tax advantages, protected savings, etc.)

We do not think that mandatory private schemes would be a solution in the Caribbean region. We prefer to increase the effectiveness of the current public pillars and to develop the supplementary private pillars.

Many forms of the supplementary voluntary pension schemes could be feasible. Privately managed DB or DC, partially or fully guaranteed funds with closed or open membership, operated independently or supported by employers or banks or insurance companies, and so on. But the institutional background of these institutions should be strictly regulated and the supervision of the managing institution is a very important task. The free movement of labour market is supported in the region, but the rules and regulation of private pension funds are different. The establishment of cross -border private funds would be preferable. It would be useful also for those Member States which have an underdeveloped or small capital market.

\subsection{Solidarity within the Public Pension System}

In this sense 'solidarity' means when some benefits are paid from other persons' taxes or contributions. Some kind of solidarity is generally accepted. But the question is whether solidarity must be solved within the pension system or it is a task of welfare systems.

I think, solidarity is a substantive characteristic of Social Security Systems. It works properly when more people pay contributions and only less people are needy. But in case when the majority of a society is needy, the concept itself could become untreatable. Contributors have no incentives to pay as they know they will get fewer benefits what would be justified (according to actuarial theory).

There are some alternative ways to apply the principle of solidarity in the pension system. The simplest way is to set up a minimum pension. It means that if the calculated (earned) pension is less than the minimum, a 'top-up' is applied. Almost all the CARICOM countries ${ }^{14}$ apply programs of minimum pension, but the amounts are different

If the sum of minimum pension is too low, it is not suitable to protect pensioners from poverty. Less than 100 US\$ monthly payment is probably too low. (It is the case in Dominica, Belize, Grenada, and also in Guyana). On the other hand, it could cause some contradictory situations when the minimum pension is higher than the majority of the earned (calculated) pensions. In Trinidad and Tobago less than 2 percent of the number of pensioners receive retirement benefit in excess of TT\$ 3000 (what is the minimum pension) with the highest monthly payment being TT\$ $3636 .{ }^{15}$ A too high minimum pension could be deterrent incentives for paying high contributions. It could be contradictory when the minimum pension is defined as a sum, but the maximum pension is given as a percentage of pensionable earnings.

For example in Barbados, the minimum weekly pension is $179 \mathrm{~B} \$$, the maximum is $60 \%$ of the average of covered earnings. In our sample case (see Annex 3) when we supposed that the average of pensionable monthly earnings is $1000 \mathrm{~B} \$$, it means that the maximum monthly pension would be only $600 \mathrm{~B} \$$, that is weekly $150 \mathrm{~B} \$$. How much should be the weekly pension: 150 or $179 \mathrm{~B} \$$ ?

It would be reasonable if both minimum and maximum pensions were defined as a percentage of national average of pensionable earnings or as a percentage of minimum wages (if it is applicable). At this moment there is only one country in the region (Guyana) where the minimum pension is connected to the wages ${ }^{16}$.

\footnotetext{
${ }^{14}$ Except Haiti, and no information on Montserrat and Suriname

${ }^{15}$ It is peculiarly interesting that Trinidad and Tobago has the most complicated contribution and pension calculation system. It is hardly understandable why does this complicated system is necessary, if the final end is an almost flat pension

${ }^{16}$ In Guyana the minimum monthly pension is $50 \%$ of the legal minimum wage for public sector workers (about 100 US\$)
} 
The social assistance programs are also common in the region. To avoid the problems it would be desirable if the social assistance programs were financed by governmental sources. But in several Member States (Antigua and Barbuda, Belize, Dominica, Grenada, Saint Lucia, Saint Vincent and the Grenadines) the social assistance programs are financed by the contributions, and only in the other countries ${ }^{17}$ are the total costs of the social assistance covered by the government.

Most of the countries have lump sum payments as part of social assistance programs. These lump sums are generally low. We do not think that it is suitable for any kind of protection.

The non-contributory pension might probably be the most effective way to protect old-age persons from poverty. There are non-contributory pensions in several CARICOM Member States. (Antigua and Barbuda, the Bahamas, Barbados, Belize, Guyana, St Kitts and Nevis, Trinidad and Tobago.) The range of the monthly payments of social assistance is between $40 \%$ and $100 \%$ of the minimum pensions. All the non-contributory benefits are means-tested or income-tested.

Some of local experts do not believe in the necessity of means-tested social assurance programs. According to their views, means-testing is too costly and difficult to control. It is purely a traditional opinion that a non-contributory system could be operated only in a mean-tested way. But this opinion is debatable. For example, the so-called basic (or flat) pension concept could be workable in such a way when a fixed sum of benefits is paid to all persons above a certain (high) age in the country (or in the region). This concept of basic pensions has not been generally accepted. The participants of the consultations also were uniformly against this concept. But we should not forget that the traditional public systems were designed for employed persons. Even if the regulation on Social Security is fair and sophisticated, more and more people will not be qualified, and a significant share of old -age persons will need some kind of support from the society. The basic pension concept could help to avoid these problems of the society.

\subsection{Adequacy of Pension Contributions}

We have discussed how different the contribution rates are in the CARICOM Member States. Now we ask how much ought to be a well-designed contribution rate?

Let us assume a theoretical relations! Basic vertical equilibrium of PAYGO systems in a period:

Pensions paid out $=$ Contributions paid in

Let us use the following categories: r: Rate of pension contribution; E: Total sum of pensionable earnings ;

SP: Total sum of paid pensions; SC: Total sum of paid contributions $\mathrm{P}$ : Nr. of pensioners $\mathrm{C}: \mathrm{Nr}$. of contributors

With these categories (1) could be written in the following forms:

If $\mathrm{SC}=\mathrm{SP}$, where

$$
S C=r \cdot \frac{E}{C} \cdot C=\text { contribution rate } \cdot \text { average earnings } \cdot \text { number of contributors }
$$

and $S P=\frac{S P}{P} \cdot P=$ averagepension $\cdot$ numberofpensioners, than $r \cdot \frac{E}{C} \cdot C=\frac{S P}{P} \cdot P$

from here $\quad r=\frac{\frac{S P}{P}}{\frac{E}{C}} \cdot \frac{P}{C}=\frac{\text { average pen sions }}{\text { average earnings }} \cdot \frac{\text { number of pensioners }}{\text { number of contributors }}$

that means: Adequate rate of pension contribution = Replacement Ratio $\cdot$ Dependency ratio

If the effective rate of pension contribution is lower or close to the adequacy, the public pension system of the country is going to fall into trouble. First they have to use their reserves, but the reserves finally would be exhausted in a limited period.

The adequacy of the contribution level might be controlled on the base of the required rate of contribution principle (see Table 2).

\footnotetext{
${ }^{17}$ In Barbados only the deficit is financed by the government, no information on Montserrat and Suriname

International Journal of Humanities Social Sciences and Education (IJHSSE) Page | 48
} 
Table2. Adequacy of Pension Contributions in CARICOM Member States

\begin{tabular}{|c|c|c|c|c|c|c|c|c|c|}
\hline & \multirow{2}{*}{$\begin{array}{c}\text { Number of pensioners as a } \\
\text { percentage of number }\end{array}$} & \multirow{2}{*}{$\begin{array}{c}\text { Current replacement of } \\
\text { pensions at average level } \\
\text { of earnings }\end{array}$} & \multicolumn{6}{|c|}{$\begin{array}{l}\text { Required rate of pension contributions } \\
\text { if the expected replacement ratio }\end{array}$} & \multirow{2}{*}{\begin{tabular}{|c|}
$\begin{array}{c}\text { Effective } \\
\text { contribution rate }\end{array}$ \\
2014 \\
\end{tabular}} \\
\hline & & & $30 \%$ & $40 \%$ & $50 \%$ & $60 \%$ & $70 \%$ & $80 \%$ & \\
\hline Antigua and Barbuda & $15,4 \%$ & $45,0 \%$ & $5 \%$ & $6 \%$ & $8 \%$ & $9 \%$ & $11 \%$ & $12 \%$ & $10 \%$ \\
\hline The Bahamas & $20,4 \%$ & $53,5 \%$ & $6 \%$ & $8 \%$ & $10 \%$ & $12 \%$ & $14 \%$ & $16 \%$ & $9,05 \% *$ \\
\hline Barbados & $30,3 \%$ & $52,50 \%$ & $9 \%$ & $12 \%$ & $15 \%$ & $18 \%$ & $21 \%$ & $24 \%$ & $15,86 \% *$ \\
\hline Belize & $9,6 \%$ & $55,0 \%$ & $3 \%$ & $4 \%$ & $5 \%$ & $6 \%$ & $7 \%$ & $8 \%$ & $12 \%$ \\
\hline Dominica & $22,2 \%$ & $62,0 \%$ & $7 \%$ & $9 \%$ & $11 \%$ & $13 \%$ & $16 \%$ & $18 \%$ & $10,75 \%$ * \\
\hline Grenada & $14,6 \%$ & $50,0 \%$ & $4 \%$ & $6 \%$ & $7 \%$ & $9 \%$ & $10 \%$ & $12 \%$ & $9 \% *$ \\
\hline Guyana & $33,7 \%$ & $55,0 \%$ & $10 \%$ & $13 \%$ & $17 \%$ & $20 \%$ & $24 \%$ & $27 \%$ & $14 \% *$ \\
\hline Haiti & $12 \%$ & $33,3 \%$ & $4 \%$ & $5 \%$ & $6 \%$ & $7 \%$ & $8 \%$ & $10 \%$ & $12 \%$ \\
\hline Jamaica & $10 \%$ & $59,9 \%$ & $3 \%$ & $4 \%$ & $5 \%$ & $6 \%$ & $7 \%$ & $8 \%$ & $5 \% *$ \\
\hline Monserrat & na & $46,0 \%$ & & & & & & & $9 \%$ \\
\hline St Kitts and Nevis & $13,3 \%$ & $54,0 \%$ & $4 \%$ & $5 \%$ & $7 \%$ & $8 \%$ & $9 \%$ & $11 \%$ & $10 \% *$ \\
\hline Saint Lucia & $8,8 \%$ & $59,5 \%$ & $3 \%$ & $4 \%$ & $4 \%$ & $5 \%$ & $6 \%$ & $7 \%$ & $10 \% *$ \\
\hline St Vincent and the Grenadines & $11,2 \%$ & $50,0 \%$ & $3 \%$ & $4 \%$ & $6 \%$ & $7 \%$ & $8 \%$ & $9 \%$ & $8 \% *$ \\
\hline Suriname & na & & & & & & & & \\
\hline Trinidad and Tobago & $24,4 \%$ & $50 \% * *$ & $7 \%$ & $10 \%$ & $12 \%$ & $15 \%$ & $17 \%$ & $20 \%$ & $11 \%$ \\
\hline
\end{tabular}

We can see that there are six countries where the current level of contributions is not fully adequate for the current level of pensions: In the Bahamas, in Barbados, in Dominica, in Guyana, in Jamaica and in Trinidad and Tobago where the total contribution rate is lower than would be required by the current level of replacement ratio of pensions.

To protect all the Social Security systems of CARICOM Member States from future problems, and to help the harmonization process, it would be reasonable if the contribution rates were not below the theoretically adequate level for a minimum of $50 \%$ of replacement ratio. The current level of contributions is not adequate for this recommendation in several Member States: The Bahamas, Guyana and Trinidad and Tobago should increase their contribution rates to fulfil this recommendation, and it is worth considering this problem also in Dominica and Jamaica. We could take notice in these countries that the current rate of contribution is not satisfactory for their own current pension replacement at level the average earnings.

\subsection{Qualification for Retirement Pensions}

Eligibility requirements for full old-age (retirement) pensions generally consist of two main criteria: the retirement age, when pensions could be claimed, and the number of contributions that qualify for full pension.

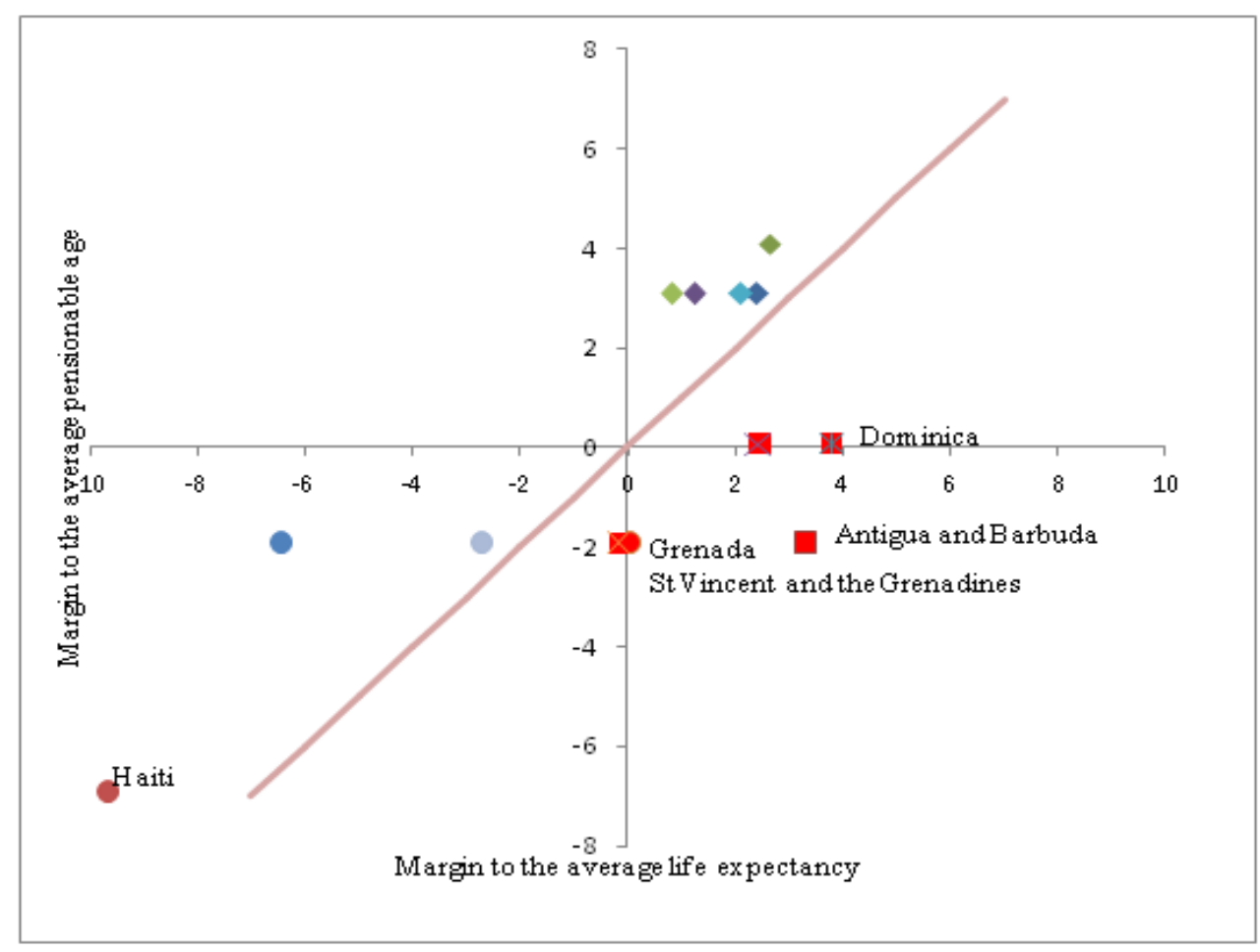

Chart2. Normal Retirement Age as a Function of Life Expectancy in the CARICOM 
There are differences in the normal retirement age (see Annex ). The mean of normal retirement age in the CARICOM Member States is 62, but in Haiti it is 55, while in Barbados 66.

The retirement ages could depend on the life expectancies. In case of countries where the life expectancy is higher than the average life expectancy of the region (countries with positive margins to the average life expectancy18) we might expect that the effective pensionable age would be higher than the average in the region (that is the margin to the average pensionable age would be also positive). But differences in retirement age are not correlated with the differences in life expectancy.

In the countries below the linear line of the margin to the average retirement age to the margin of life expectancy (Antigua and Barbuda, Dominica, Grenada, St Kitts and Nevis, St.Vincent and the Grenadines) it would be desirable to increase the current retirement age.

The length of service period is defined by the number of contributions. Most of the countries have additional requirements for the minimum number of paid contributions. This distinction might be important if the number of credited contributions could be significantly different from the number of paid contributions.

There are some differences also in the minimum number of contributions. Nine CARICOM Member States require 500 weeks of contributions (about 10 years) for full pensions (See Annex), but there are two countries were the minimum number of contributions is 20 years or more (Haiti and Jamaica).

It seems to be unreasonable that some countries define the minimum period for qualification in weeks, others in months or in years. The minimum of the required service period could be defined in years also, in case when the pension calculation is defined in weeks.

The minimum service period could be defined in line with the expected length of pension period. It might be a reasonable expectation, that the length of contributory period would be longer than the life expectancy at retirement.

If we suppose the average of life expectancy at birth is about 73 and the average retirement age is about 62 , the minimum of required service period should be above 12 years. Recently five Member States fulfil this expectation: Guyana, Haiti, Jamaica, Saint Lucia, and Trinidad and Tobago. It is worth considering raising the minimum number of contributions where the current qualifying conditions are set at 500 weeks or less.

\subsection{Pension Formula}

Many different types of pension formulas could be used depending on what factors are taken into consideration. From actuarial point of view the two most important factors are the age at retirement and the total sum of contributions paid. At this moment the pension formulas in the national pension systems in the region generally depend directly neither on the effective age at retirement nor on the sum of paid contributions19.

The pension formula could depend directly on the life expectancy at retirement. In this case - from actuarial point of view - there is no need to insist on any sole pensionable age. If someone is retiring earlier, he would get fewer pensions than those who retire later (with the same contribution history).

The structures of pension formulas in most Member States20 are similar: up to the minimum number of contributions they promise a fix percentage of pensionable earningsand for the contributions above the minimum level they pay a proportional increase. But the parameters of the calculations are quite different. The differences of pension calculations could be derived from three factors: the calculation of pension base, the pension percentages for the contributions and the special arrangements (e.g. a sum of basic pension (Jamaica) high minimum pension (Trinidad) or bonuses for deferral (Dominica)).

In most cases pensions are based on average earnings but the calculation of average earnings could be different The period of calculation of covered earnings is varying from the last 5 years (Guyana) to the number of years of the whole career (in five countries from the eleven examined). The selected years for the calculation of the average earnings in the period could be the best 3 years (in four

\footnotetext{
${ }^{18}$ The margin means the difference between the effective figures and the average

${ }^{19}$ In Jamaica ( above a flat sum of basic pension) the pension is based on the sum of contributions paid

${ }^{20}$ The pension formula is different only in Haiti and Jamaica. See later.
} 
countries) or the best 5 years (in 5 countries). Only Trinidad and Tobago uses the career average of earnings as pension base.

The career average of earnings is a more adequate base for pensions than the average of earnings in a few selected years. We could experience cases when a person is contributing only on low earnings in most years of his career and in the last few years he deliberately pays far more contributions. If the pension calculation is based only on these last few years' earnings he will get a higher pension than what would be actuarially fair according to their total contributions paid.

There is no valorisation 21 of earnings in calculation techniques in the region. If we take into consideration a longer period in calculation of average earnings or the inflation is high(er), the valorisation would be necessary.

The pension percentages set the pension payment functions. It shows how much percentage of the pension base is paid as a function of number of contributions. These functions are based on the definitions of the pension calculations which are very different in the region. In the 14 Member States22 we found 11 different definitions:

- $30 \%$ of the insured's average earnings plus $1 \%$ for each 50 week period of contributions exceeding 500 weeks of contributions. (The Bahamas, Dominica, Grenada)

- $30 \%$ of the insured's average earnings plus $2 \%$ for each 50 week period of contributions exceeding 500 weeks of contributions, up to 750 weeks, plus $1 \%$ for each 50 week period of contributions exceeding 750 weeks of contributions. (Belize, St Kitts and Nevis)

- $25 \%$ of the insured's average earnings plus $1 \%$ for each 50 week period of contributions exceeding 500 weeks of contributions, up to $50 \%$ of the max monthly earnings used to calculate benefits. (Antigua and Barbuda)

- $40 \%$ of the insured's average earnings plus $0.1 \%$ for each month exceeding the 180 months. (St Lucia)

- $40 \%$ of the insured's average earnings plus $1 \%$ for each 50 week period of contributions exceeding 750 weeks of contributions. (Guyana)

- $20 \%$ of the insured's average earnings plus $0.65 \%$ for each 25 week period of contributions exceeding 500 weeks of contributions (Montserrat)

- $16 \%$ of average annual earnings for 150 weeks of contributions plus $1 \%$ for each 25 -week period up to 500 weeks, plus $0.5 \%$ for each 25 -week period exceeding 500 weeks (St Vincent and the Grenadines)

- $2 \%$ of the insured's average annual earnings for the first 20 years plus $1,25 \%$ for each year of contributions exceeding 20 years $\left(\right.$ Barbados $\left.^{23}\right)$.

- $30 \%$ to $48 \%$ of the average of weekly earnings plus $0,56 \%$ to $0,71 \%$ according to 16 wage classes for each 25-week period of contributions exceeding 750 weeks (Trinidad and Tobago) .

- $33,3 \%$ of the insured's average monthly earnings (Haiti)

- $2800 \mathrm{~J} \$ /$ weeks plus J $\$ 0,06$ weekly for every J $\$ 13$ of contributions paid. (Jamaica)

Among these definitions only two are fundamentally different from the others: the flat pension rule (in Haiti), and the basic pension plus when the contributory pensions depend on the sum of contributions (in Jamaica). All the others differ only in parameters.

The effective payment functions are formed also with some limits set by the sum of minimum or maximum pensions. In some cases the sum of paid pensions differs significantly from the earned (calculated according to the pension payment rules) (e.g. in Barbados, The Bahamas and Trinidad and Tobago).

\footnotetext{
${ }^{21}$ Valorisation is a technique when the value of past earnings is adjusted to the changes of their values in time.

${ }^{22}$ We had no data from Suriname.

${ }^{23}$ For those who were younger than age 47 in December 2002
} 
As a result, the payment functions are different in the Member States. . Chart 3 shows the pension payment functions in selected counties. We could see that at the same pension base one can get significantly different sums of pensions depending on what country he was qualified.

Probably the most serious barrier to develop the harmonization of the Social Security systems in the CARICOM Member States is the difference in pension payment functions. Any type of flat payments (flat pension or high minimum pension that resulted in practice in flat payments) could deform the payment function (Haiti and Trinidad). The other source of differences is that the increase of contributions is differently rewarded in different countries which could result in contradictions in case of the pension totalisation.

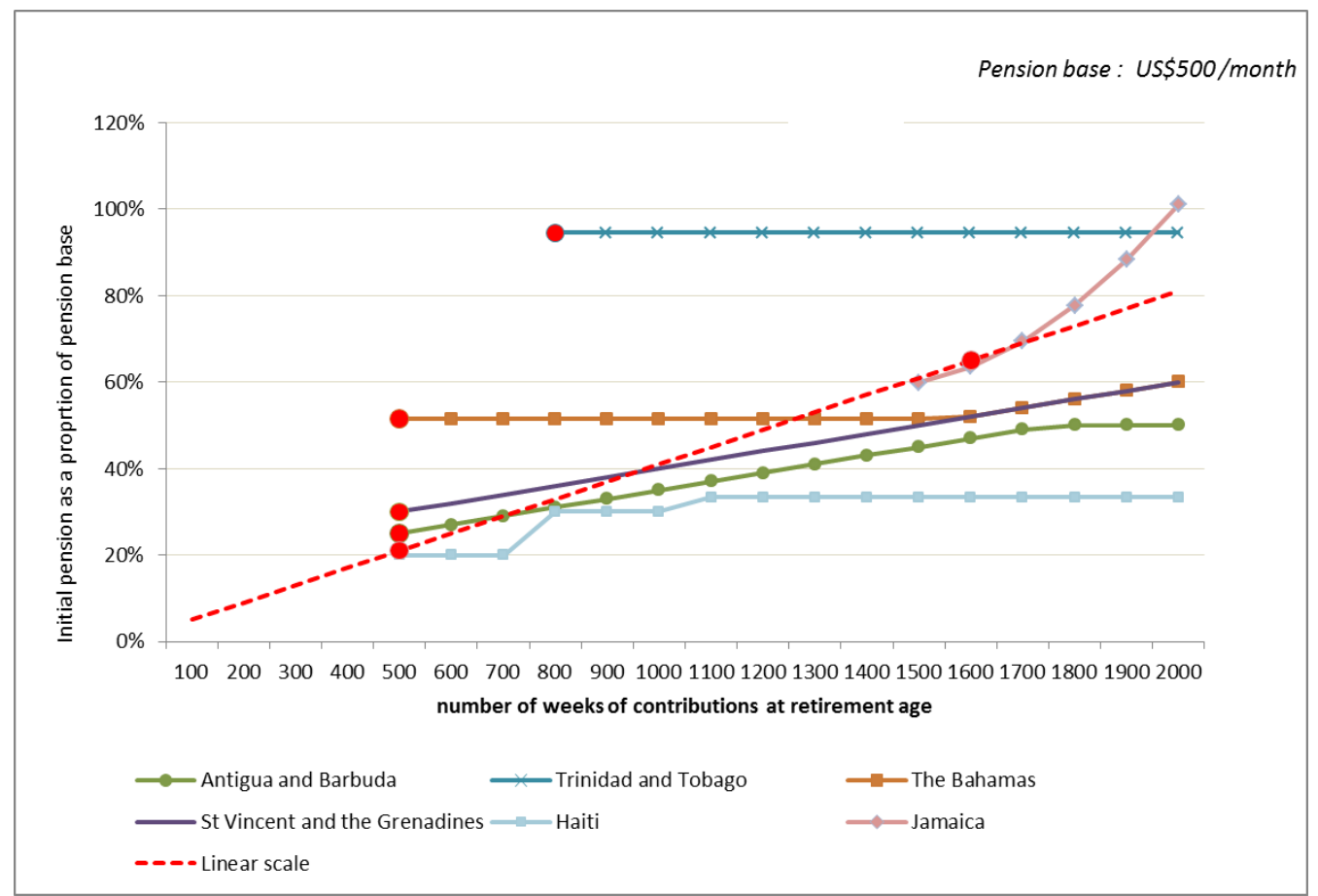

Chart3. Initial Pensions as a function of number of contributions in selected CARICOM Member States

\section{Risk Exposure of Public Pension Systems in Caricom Member States}

The member states could face different kinds of risk affecting their Social Security systems. Unequal level of risk of operating the public pension systems could hinder the harmonization process. In this part of the report we try to detect what type of risks could have influence to the process of harmonisation of the pension systems in the CARICOM member states. The measure of the risks can signal how much effort should be taken in order to make steps towards harmonization.

Now we try to make a systematic overview on the risk factors.

For measuring the risk exposure of the public pension system we can use several measures based on data of the Member States. In order to appraise the importance of the detected risk factors we use a simplified method for ranking. We selected the most important risk factors which could affect the Social Security system, and then index-numbers were determined based on the available data. Each index was ranged in risk classes: we created classes of low (lower than average), medium (average), and high (higher than average) risks. The range of measures of countries increases from 1 (the most risky value) to 3 (the less risky value of the selected measure).24

For appraisal of each factor we can use more than one measure. The final appraisal is given as an average of the grades of the single measures.

The following types of risk factors are taken into consideration:

- Socio-Economic Environment

\footnotetext{
${ }^{24}$ All kind of ranking is subjective. This method has also subjectivity but it could be used as a tentative qualification of risks
} 
- Demography

- Status of Social Security

- Pension Design

Total risk exposure of Social Security systems in the CARICOM Member States are measured as the average of the four types of risk measures as a percentage of maximum level of risk exposure. 25 The calculations of the measures based on internationally published statistical data. The result of this measurement is a grouping of the countries.

We form three groups of countries: those countries belong to the first group where the risk exposure is the lowest, the second group consists of countries with average level of risk, and the third group consists the countries where the harmonisation process is touched by the highest risk. The risk clusters are formed in the four groups separately and according to the total risk exposure.

In case of risk factors of the socio-economic environment we took into consideration the most important ones that could have an effect on Social Security systems.

The risk factors and the measures on environmental risk are summarized as follows:

- $\quad$ Small size ( population)26

- High or increasing inflation ( consumer price index; change of inflation)

- under-development (GDP/capita; Grows of real GDP; Share of population below poverty line)

- Low economic activity ( Labour force participation rate, Change in economic activity rate $15+$;employment to population $15+$; unemployment rate)

- Low wages ( annual average wages US\$; Average disposable Salary )

The countries with a population below 100000 (Antigua and Barbuda, Dominica, Montserrat and St Kitts and Nevis) could have different problems to operate their Social Security systems than those of higher size. Because of this the size could be taken into consideration as a risk factor. But the total risk of environment does not depend seriously on the size. It is easily understandable that economic development has the main effect on environmental risk. The differences in development could be more important in the harmonization processes. The risk of development is evitable different for example in the Bahamas and in Haiti. In case of low economic activity (like it is in Grenada) the social security might have different problems than in countries of high economic activities (e.g. in $\mathrm{St}$ Kitts and Nevis). Or the different level of inflation or wages could result in different level of environmental risk of social security.

The highest environmental risk was measured in St Vincent and the Grenadines, in Dominica, in Jamaica, in Grenada, in Saint Lucia and in Haiti. The environmental risk is the lowest in The Bahamas, in St Kitts and Nevis, in Belize and in Barbados.

The connection between the demography and the problems of Social Security systems is well known. The small number of insured group could be a danger for risk sharing, decreasing rate of fertility or the ageing could threaten the future financing of pensions. The question is whether any differences could be detected in the countries' demographic risks.

The risk factors and the measures of demographic risk used in the evaluation are summarized as follows:

- .small number of insured persons (population; growth of population; share of population $65+$ )

- low fertility (fertility rate, change in crude birth rate)

- ageing (old age dependency ratio, change of old age dependency ratio)

\footnotetext{
${ }^{25}$ The minimum level of risk exposure is when a country belongs to the lowest risk group in all the four types of risk. In this case the average of risk measures would be 3. The measure of total risk exposure is : 1 minus average of the four risk measures

${ }^{26}$ The measures used for risk evaluation are in brackets.
} 
The risk of small number of insured population is high in Montserrat but not in any of the other countries. The low or decreasing rate of fertility rate is not a risk in Belize, in Grenada, in Guyana, in Haiti, and in Suriname, but in other countries it has not been unimportant any more, but this risk is high only in Montserrat. The danger of ageing is present even now in Saint Lucia, in Trinidad and Tobago and in Jamaica.

According to the summary of demographic risk exposure, we can see that the differences in demographic risk exposure are bigger than in the case of economic risks. The countries where the demographic risk is high are: Montserrat, Saint Lucia, St Kitts and Nevis. At the same time the demography is not threatening to the Social Security system in Belize, Grenada, Guyana, Haiti and Suriname.

We have discussed the problems that could derive from the differences of the Social Security systems in the Member States. Now we try to detect what kinds of risks are effective in the countries' Social Security systems. Insufficient level of contributions, low coverage, relatively small reserves or high operational cost could be taken into consideration.

The risk factors and the measures of the status of Social Security systems used in the evaluation are summarized as follows:

- insufficient level of contributions (active contributors to pensioners;adequacy of contributions)

- low coverage (contributors to employed; pensioners to populations 65+; average pensions to average insurable wages; SS's expenditure as a percentage of GDP)

- insufficent level of reserves (pension reserves as a persentage of GDP; reserve-expenditure ratio)

- high expenses (administrative expenses as a percentage of contributory income)

The lowest risks of pension design are in Saint Lucia and in St Kitts and Nevis27, but the risk of pension design is not high even in Belize and in the Bahamas. The highest level of risk of pension design is in Antigua and Barbuda, in Barbados, in Grenada, in Haiti and in Trinidad and Tobago. The main factor in the level of risk of pension design is the weak qualification (in Antigua and Berbuda, in Grenada and in St Vincent and the Grenadines), and the extraordinary amount of minimum pensions (in Trinidad and Tobago and even in Barbados).

The risk of pension payment function is measured by the "distance" 28 of the current pension payment functions and the proposed possible harmonised payment function. As it was mentioned previously Haiti and Jamaica has theoretically different payment functions, and Barbados and Trinidad use high minimum pensions. It resulted in high risk of differences of payment functions.

The risks of insufficient level of contributions are measured by share of active contributors to the number of pensioners (how many contributors should pay for one pensioner?) and the adequacy of contribution (the current rate of contribution compared to the theoretical rate of contribution required for replacement of 50\%). The risk of insufficient level contribution is low in Belize and St Vincent and the Grenadines, while in Trinidad and Tobago and in Guyana it is higher than anywhere else.

The risk of low coverage are measured by the share of contributors to the number of employed persons (what is the share of employed persons paying contributions?), by the number of pensioners to the number of population at age above 65 and by the share of the sum of average pensions to the sum of average earnings and share of total expenditure of Social Security to the GDP. According to our measures the lowest risk of coverage is in Barbados and the biggest is in Belize and Jamaica.

The level of reserves is measured by the share of the market value of reserves to the GDP and the reserve-expenditure ratio. The risk of insufficient serves is high only in Guyana, but in Grenada, in St Vincent and the Grenadines, in Antigua and Barbuda, in Saint Lucia and in St Kitts and Nevis reserves are satisfactory.

\footnotetext{
${ }^{27}$ The pension payment functions are similar in these countries.

${ }^{28}$ Distance is measured by the average of squared odds of the values of functions.
} 
The administrative expenses of Social Security are generally high. Only Barbados and Trinidad and Tobago have low risk of operations. The risk of costs is extremely high in Montserrat, but it is high also in Belize and in the Bahamas.

The highest risks of current status of the Social Security system belong to Guyana, The Bahamas, Belize and Jamaica. And the group of lowest risk of social security status consists of St Vincent and the Grenadines, St Kitts and Nevis and Saint Lucia. In Belize the high risk derived mainly from the low level of age and the insufficient level of reserves, but the administrative expenses are also higher than average. In Guyana the insufficient level of contributions and the level of reserves are the main problem. In Jamaica, the low coverage, and in the Bahamas the high administrative expenses are the main factors of risk. The administrative expenses of the Social Security system are also very high in Montserrat. The risk of Social Security status is the lowest in St Kitts and Nevis, but the risk of SS status is lower than the average also in Barbados, Dominica, Grenada and Saint Lucia.

The risk factors and the measures of the design of public pension systems are summarized as follows:

- Early qualification (normal retirement age; minimum of contributory period in years)

- Inadequate pension calculation (minimum pensions as a percentage of average wages; number of years for average earnings calculation)

- Differences in Pension functions ( distance from the "ideal" pension function29)

The lowest risks of pension design are in Saint Lucia and in St Kitts and Nevis30, but the risk of pension design is not high even in Belize and in the Bahamas. The highest level of risk of pension design is in Antigua and Barbuda, in Barbados, in Grenada, in Haiti and in Trinidad and Tobago. The main factor in the level of risk of pension design is the weak qualification (in Antigua and Berbuda, in Grenada and in St Vincent and the Grenadines), and the extraordinary amount of minimum pensions (in Trinidad and Tobago and even in Barbados).

The risk of pension payment function is measured by the "distance" 31 of the current pension payment functions and the proposed possible harmonised payment function. As it was mentioned previously Haiti and Jamaica has theoretically different payment functions, and Barbados and Trinidad use high minimum pensions. It resulted in high risk of differences of payment functions.

Taking into consideration all the four types of risk we could see a heterogenous risk map of the countries. It could interfere the harmonization process

The total risk exposure of social security systems in the caricom member states are summarized in Table 3.

Table3. Risk Exposure of Social Security Systems in the CARICOM Member States

\begin{tabular}{|c|c|c|c|c|c|c|}
\hline \multirow[b]{2}{*}{ Belize } & \multirow{2}{*}{$\begin{array}{c}\text { RISK OF } \\
\text { ENVIRONMENT } \\
\text { low }\end{array}$} & \multirow{2}{*}{\begin{tabular}{|c|}
$\begin{array}{c}\text { RISK OF DEMOGRAPHIC } \\
\text { TRENDS }\end{array}$ \\
low \\
\end{tabular}} & \multirow{2}{*}{$\begin{array}{c}\text { RISK OF SS's } \\
\text { STATUS } \\
\text { high }\end{array}$} & \multirow{2}{*}{$\begin{array}{c}\text { RISK OF PENSION } \\
\text { DESIGN } \\
\text { avergae }\end{array}$} & \multicolumn{2}{|c|}{$\begin{array}{c}\text { TOTAL RISK EXPOSURE } \\
\text { OF PUBLIC PENSION } \\
\text { SYSTEM }\end{array}$} \\
\hline & & & & & $29,8 \%$ & mild risk \\
\hline St Kitts and Nevis & high & high & low & low & $30,1 \%$ & mild risk \\
\hline The Bahamas & low & average & high & avergae & $31,8 \%$ & mild risk \\
\hline Saint Lucia & low & high & low & low & $32,1 \%$ & mild risk \\
\hline Guyana & average & low & high & avergae & $34,5 \%$ & mild risk \\
\hline Grenada & high & low & average & high & $35,6 \%$ & medium risk \\
\hline St Vincent and the Grenadines & high & average & low & avergae & $37,5 \%$ & medium risk \\
\hline Dominica & high & & average & avergae & $37,7 \%$ & medium risk \\
\hline Barbados & low & average & average & high & $38,0 \%$ & medium risk \\
\hline Antigua and Barbuda & average & high & average & high & $39,7 \%$ & medium risk \\
\hline Jamaica & high & average & high & avergae & $39,8 \%$ & medium risk \\
\hline Trinidad and Tobago & average & average & high & high & $41,1 \%$ & vulnerable \\
\hline Haiti & high & low & & high & na & vulnerable \\
\hline Montserrat & & high & & & na & vulnerable \\
\hline Suriname & average & low & & & na & \\
\hline
\end{tabular}

\footnotetext{
${ }^{29}$ We took a pension function as an ideal, when for all contributory weeks are linearly rewarded in pensions

${ }^{30}$ The pension payment functions are similar in these countries.

${ }^{31}$ Distance is measured by the average of squared odds of the values of functions.
} 
We could observed that the differences in level of risks in the countries could create obstacles to harmonisation. The figures of measures themselves are meaningless, but we could say that the majority of the countries has tolerable level of risk. Trinidad and Tobago, Haiti and Montserrat have more risks against harmonisation. The group with the lowest level of risk against harmonisation consists of Belize, The Bahamas, Saint Lucia, Grenada, St Kitts and Nevis and Guyana. Hopefully in these countries the harmonisation process would be easier than in the other countries. But even these countries have at least one factor with high risk.

The individual risk levels of the countries are heterogenous and not consistent across the risk factors. There is no country where all types of risk are high or all are low and all the countries have at least one type of risk of high level. The results indicate that reform is needed within the national systems before forcing high level of integration of the Social Security systems.

\section{RECOMMENDATIONS}

After a wide range of topics discussed in this report, we would like to underline some steps to be made within the national systems what could be useful for the future advance in harmonisation. The harmonization of pension regulations is not an easy task and it could last for a long time. On the other hand, the harmonization itself would not solve a lot of existing problems of the current pension systems. The low coverage of non-employed persons, the evasion of Social Security contributions, and the decreasing number of contributors will remain and more regular information on accumulated pension rights will not be available. Because of this, some amendments of the regulation of national systems would be desirable.

We know that the traditions and the trust in the current national regimes are strong which could be the main barrier against proper harmonization. But some steps could be made within the national systems before harmonisation would be tightened.32

\subsection{Separation of the Functions of Social Security System}

It is useful if the two main functions of the pension system, which are the insurance against poverty and a fair income replacement, were separated. Only the earnings related benefits should be covered by contributions. All kinds of non-contributory benefits to insure against poverty should be financed by the state budget. Even the minimum pensions might be financed by public resources. As a first step the contributions for benefits what might be touched in any kind of harmonisation process would be separated. That means that the contributions for pension benefit would be defined independently from contributions for other kind of benefits. Only in this case would be the level of contributions of the countries comparable.

\subsection{Modification of Normal Retirement Age}

The same normal retirement age would be set in the region without serious modification of the current regulations. Because of the increasing life expectations, about age of 65 would be desirable. To retire at a different age, namely at the age of normal retirement age according to the current regulation of a country might be possible by the general introducing of regulated early and or deferred pensions.

\subsection{Rationalisation of Pension Payment Functions}

We are convinced that the differences in pension payment functions are among the most serious barriers of harmonisation. We could identify serious differences of payment functions in the region. It could cause contradictions in pension totalisation.

The main points towards harmonization of pension payment functions could be as follows:

- The minimum number of contributions might be the same in all of the Member States. To achieve a more healthy balance of active period and the period in pensions a minimum of 600-650 weeks would be advisable. If any national regulation would like to insist on qualification of fewer weeks than agreed, partial pension within the national regulation could be workable.

\footnotetext{
${ }^{32}$ Introduction any kind of modifications of the national systems correspond to the following recommendations need to different arrangements in all countries.
} 
- The minimum pension might be attached to the level of wages. Recommendation: $25 \%$ of pension base33. In case of early pensions, deferred pensions or partial pensions the calculated full pensions would be the base for minimum pensions.

- Above the minimum of pensions a linear scale of a contributory pension might be agreed. (e.g. $1 \%$ for each 25 -week period of contributions).

- The maximum of pensions could be fixed at the same level in all the countries. In order to induce the contributors it would be reasonable to increase the current level of $60 \%$ of maximum of pensions. About $75 \%$ of pension base could be advisable. But if the pensionable incomes, namely the base of contributions are maximized34, the maximum pension is not necessary at all.35

The main effects of the proposed harmonisation of pension formula could be different in each member state. We could see that this recommendation could result in some increase in pension percentages mainly in case of longer periods of contributions in most countries. On the other hand, we propose generally lower pensions for those who have shorter period of contributions. In countries of high minimum of pensions (Trinidad, Barbados and also the Bahamas) eventually significant decrease of pension percentages would be experienced in case of a short contributory period. Of course if it is sustainable for longer horizon these counties could follow paying these high minimum pensions but in case of totalisation the pensions calculated according to the harmonized function would have been counted. In Haiti (and even in Montserrat), where the pension level is far below the average pensions in the region, this harmonized pension formula would cause a significant increase in pensions, which probably is not affordable in this moment.

\subsection{More Effective Communication on Accumulated Pension Rights}

Individuals are not really informed about their acquired pension rights. It would be very useful if all citizens who is paying contribution would get information on how much their contribution (made in the given period or accumuletd in their career) "worth" concerning their future pensions.

One solution could be when all insured persons have a notional personal account36 where contributions are credited 37 . The individuals could get regular information38 on the accumulated sum of contributions. Recording the individual accounts would be a new task of the institutions which are collecting contributions.

But in pay-as-you-go systems, where the benefits are not really attached to the contributions paid, such a solution is nothing more than a reminder on contributions. It could be useful but not satisfactory enough concerning the accumulated pension rights. Without any points of reference the persons will not know whether their contributions are adequate or not, too little or too much compared with the contributions paid by others, how much pensions are "promised" for their contributions. This information could be a very good incentive for those who pay irregularly or too little.

When personal accounts are created in a country some additional investment is worthwhile to create a more sophisticated registration system on pensions.

We suggest a registration system which is feasible, easy to understand and easy to communicate. It could be a good incentive to support paying contrubutions.

Let us define a reference point for the sum of contributions in a year! The amount of contribution paid for a full time public sector worker on the average salary according to the national regulation could be calculated. We can say that this amount of contribution is worth 1 reference point that could be

\footnotetext{
${ }^{33}$ In a really harmonized system the minimum of pensions could be attached to the same amount in the region, e.g. to the average value of minimum wages of public sector workers in the region.

${ }^{34}$ In most member states there is some limitation for pensionable earnings. But the level of maximum earnings is different.

${ }^{35}$ See dotted red line in Chart3.

${ }^{36}$ There are personal accounts in one or two CARICOM member states..

${ }^{37}$ In some countries where personal accounts are existing the balance are regularly compounded by an agreed interest rate.

${ }^{38}$ It could be delivered only by internet.
} 
collected during the year. The contributions paid by an individual39 could be more (if he contributed on higher earnings than the average salary of public pension workers) or it could be less than this reference amount of contribution (if his earnings were lower than the average salary of public pension workers or he contributed less than 52 weeks in the year). All the persons who paid at least one contribution during the year could get a reference point according to their registered contributions in the year40. The reference point of the year would be registered in his individual account.

The system of reference points has several advantages:

- The contributions are not connected to employment.

- The registration of long contribution history is not really necessary.

- Non-salaried people would not be forced to declare any type of service period

- Voluntary contributors could correlate the level of their contributions paid to the reference points

- Reference points could be good guidelines for the future pension promises as well 41

- All reference points collected by the individual during his career in the country could be added. The accumulation of pension rights could be detected successively.

- Valorization is not an issue and even there are no currency problems.

- All pensions could be calculated relative to a person who earned of equal to the average salary of full-time public sector workers all along his career42. In any case the only pension calculated is the pension of the full time public sector workers with average salary who is retiring at the date of retirement of the claimant. The sum of the pension of the reference person multliplied by the accumulated number of reference points of the claimants is the initial pension of the claimant.

- There are no special issues with partial pensions

- Pensions could be fairly indexed by the changes of average salary of public sector workers.

- Reference points could be used in case of totalisation by CASS.

- No immediate need to reform national pension rules or any effort for further harmonization.

Introducing a system of reference points needs well-established design and more preparation but it could solve many problems that we have addressed in this report.

\subsection{Introduction of a kind of Basic Pension}

We would like to repeat our supportive opinion on the basic pension concept 43 . A kind of basic pension could be a good solution to realise the solidarity concept.

According to this concept all persons of meeting some conditions 44 would get a regular payment of flat sum only to protect them from extreme poverty45. In a region, where a significant (and increasing) share of population over the age of 65 has no regular income, the basic pension would be the real solution to social solidarity. The sources of any kind of basic pension should not be the contributions paid by employed persons. It should be financed by a kind of consumer's taxes or value added taxes. In a transition period the sources of basic pension payment could be the accumulated surplus funds of Social Security.46

\footnotetext{
${ }^{39}$ We suppose that there are no differences in contribution rates and pension rules of public and non-public sector workers.

${ }^{40}$ The maximum value of the reference point credited in a year could be limited.

${ }^{41}$ If I get 2 reference points this year that means that my pension promise for this year is twice as it is for full time public sector workers

${ }^{42}$ All people have some information on how much are the pensions of such persons.

${ }^{43} \mathrm{~A}$ kind of basic pension system is operated in Jamaica but it is paid only for qualified contributors.

${ }_{45}^{4}$ e.g. long term residency

${ }^{45}$ The level of this kind of basic pension might be around at one third of average wages in the country.

${ }^{46}$ The introduction of a basic pension system need different measures within in all the national pension systems.
} 
After introducing basic pension payments, the Social Security system would continue to provide earnings related pension as well. It might be totally dependent on contributions. The basic pension should not be additional to the previous level of pensions. Introducing such a type of basic pension could result in some decrease in the level of earnings related pensions along with the decreasing of the contribution rates.

The beau ideal of harmonization would be if a CARICOM Basic Pension were paid to all CARICOM residents what were financed by a common pension fund. The fund itself could be built up by contributions dedicated for this pension payment what is paid by the government budget of Member States according to an agreed scale. All persons resident in any Member State would be eligible to get it above - say - the age of 70. An elaborated CARICOM Basic Pension system needs more detailed cogitations.

ANNEX OLD-Age Benefit Programs in the CARICOM Member States (1)

\begin{tabular}{|c|c|c|c|c|}
\hline & 1 & 2 & 3 & 4 \\
\hline & Antigua and Barbuda & The Bahamas & Barbados & Belize \\
\hline \multicolumn{5}{|l|}{ Social Insurance programs } \\
\hline Normal retirement age & 60 & 65 & 66 & 65 \\
\hline Minimum of contributotry period in years & 10 & 10 & 10 & 10 \\
\hline Upper limit of monthly covered earning (US\$) & 833 & 2600 & 2158 & \\
\hline Period of average earning & last 10 years & & & \\
\hline Years of average earnings' calculation & best 5 years & best 5 years & best 5 years & best 3 years \\
\hline Special qualifying conditions & & $\begin{array}{l}\text { Entitlement ceasing if the insured person } \\
\text { earns US\$ } 300 \text { or more a week !! }\end{array}$ & & retirement is not neccesary \\
\hline minimum of monthly pension in US $\$$ & 130 & 257 & 354 & 94 \\
\hline maximum of monthly pension in US\$ & 833 & $60 \%$ of average covered earnings & $60 \%$ of average covered earnings & \begin{tabular}{|l|l}
$00 \%$ or average coverea earmings up to \\
232
\end{tabular} \\
\hline benefit adjustment & according to actuarial reviews & & annually, by cost of living & \\
\hline Payable abroad & Yes & paid locally for all & yes & \\
\hline old age /retirement pension & $\begin{array}{c}25 \% \text { of the insured's average earnings plus } \\
1 \% \text { for each } 50 \text { week period of } \\
\text { contributions exceeding } 500 \text { weeks of } \\
\text { contribution }\end{array}$ & $\begin{array}{c}30 \% \text { of the insured's average earnings plus } \\
1 \% \text { for each } 50 \text { week period of contributions } \\
\text { exceeding } 500 \text { weeks of contribution }\end{array}$ & $\begin{array}{c}2 \% \text { of the insured's average annual earnings } \\
\text { for the first } 20 \text { years of contributions, plus } \\
1,25 \% \text { for each year of contributions } \\
\text { exceeding } 20 \text { years }\end{array}$ & $\begin{array}{c}30 \% \text { of the insured's average earnings } \\
\text { plus } 2 \% \text { for each } 50 \text { week period of } \\
\text { contributions exceeding } 500 \text { weeks up } \\
\text { to } 750 \text { weeks, plus } 1 \% \text { for each } 50- \\
\text { weeks exceeding } 750 \text { weeks } \\
\end{array}$ \\
\hline Deferral pensions & & plus $0,58 \%$ for each month above age 65 & & \\
\hline Early pensions & & minus $0,58 \%$ for each month before age 65 & & \\
\hline old age settlement (in US\$) & 444 & & & \\
\hline \multicolumn{5}{|l|}{ Social assistance programs } \\
\hline old age grant & & & $\begin{array}{c}\text { a lump sum of six times of average covered } \\
\text { earnings for each } 50 \text {-week periods of paid or } \\
\text { credited contributions }\end{array}$ & $\begin{array}{c}\text { a lump sum of six times of average } \\
\text { covered earnings for each } 50 \text {-week } \\
\text { periods of paid or credited } \\
\text { contributions }\end{array}$ \\
\hline minimum of old age grant in US\$ & & & & 400 \\
\hline non-contibutory old age pension (monthly, in US\$̦) & 83 & 237 & 287 & 50 \\
\hline
\end{tabular}

ANNEX Old-Age Benefit Programs in the CARICOM Member States (2)

\begin{tabular}{|c|c|c|c|c|c|}
\hline & 5 & 6 & 7 & 8 & 9 \\
\hline & Dominica & Grenada & Guyana & Haiti & Jamaica \\
\hline \multicolumn{6}{|l|}{ Social Insurance programs } \\
\hline Normal retirement age & 61 & 60 & 60 & 55 & 65 \\
\hline Minimum of contributotry period in years & 10 & 10 & 14 & 20 & 28 \\
\hline Upper limit of monthly covered earning (US\$) & 2222 & 1574 & 688 & & 1302 \\
\hline Period of average earning & last 15 years & & last 5 years & & \\
\hline Years of average earnings' calculation & best 10 years & best 5 years & best 3 years & last 10 years & \\
\hline Special qualifying conditions & & & retirement is not neccesary & & \\
\hline minimum of monthly pension in US $\$$ & 14 & 69 & 93 & & \\
\hline maximum of monthly pension in US $\$$ & \begin{tabular}{|c|}
$60 \%$ of average covered \\
earnings
\end{tabular} & 587 & $\begin{array}{c}60 \% \text { of average covered } \\
\text { earnings }\end{array}$ & & \\
\hline benefit adjustment & $\begin{array}{l}\text { in every } 3 \text { years } \\
\text { according to } C P I\end{array}$ & periodically & & ad hoc & \\
\hline Payable abroad & yes & yes & no & & yes \\
\hline old age /retirement pension & \begin{tabular}{|c|}
$30 \%$ of the insured's \\
average earnings plus \\
$1 \%$ for each 50 week \\
period of contributions \\
exceeding 500 weeks of \\
contribution \\
\end{tabular} & \begin{tabular}{|c|}
$30 \%$ of the insured's average \\
earnings plus $1 \%$ for each 50 week \\
period of contributions exceeding \\
500 weeks of contribution
\end{tabular} & $\begin{array}{c}40 \% \text { of the insured's average } \\
\text { earnings plus } 1 \% \text { for each } 50 \\
\text { week period of contributions } \\
\text { exceeding } 750 \text { weeks of } \\
\text { contribution }\end{array}$ & $\begin{array}{l}33,3 \% \text { of the insured's average } \\
\text { earnings in the last } 10 \text { years }\end{array}$ & 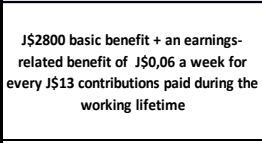 \\
\hline Deferral pensions & \begin{tabular}{|c|} 
plus $6 \%$ for each \\
comlpelete year aove \\
pensionable age
\end{tabular} & & & & \\
\hline Early pensions & $\begin{array}{c}\text { minus } 0,5 \% \text { for each } \\
\text { month before } \\
\text { pensionble age }\end{array}$ & & & & \\
\hline old age settlement (in US\$) & & & & $\begin{array}{l}\text { the contributions are refunded } \\
\text { without accrued interest }\end{array}$ & 521 \\
\hline Social assistance programs & & & & no & no \\
\hline old age grant & \begin{tabular}{|c|} 
a lump sum of three \\
times of average \\
weekly covered \\
earnings for each $50-$ \\
week periods of paid or \\
credited contributions
\end{tabular} & $\begin{array}{c}\text { a lump sum of five times of average } \\
\text { weekly covered earnings for each } 50 \\
\text { week periods of paid or credited } \\
\text { contributions }\end{array}$ & $\begin{array}{l}\text { a lump sum of } 8,33 \% \text { of average } \\
\text { annual covered earnings for } \\
\text { each } 50 \text {-week periods of paid } \\
\text { or credited contributions }\end{array}$ & & \\
\hline \multicolumn{6}{|l|}{ minimum of old age grant in US\$ } \\
\hline non-contibutory old age pension (monthly, in US\$̦) & & & 37 & & \\
\hline
\end{tabular}


ANNEX Old-Age Benefit Programs In The CARICOM Member States (3)

\begin{tabular}{|c|c|c|c|c|}
\hline & 11 & 12 & 13 & 15 \\
\hline & St Kitts and Nevis & Saint Lucia & St Vincent and the Grenadines & Trinidad and Tobago \\
\hline \multicolumn{5}{|l|}{ Social Insurance programs } \\
\hline Normal retirement age & 62 & 65 & 60 & 60 \\
\hline Minimum of contributotry period in years & 10 & 15 & 10 & 14 \\
\hline Upper limit of monthly covered earning (US\$) & 2407 & 1852 & 1605 & 1447 \\
\hline Period of average earning & last 15 years & & last 15 years & \\
\hline Years of average earnings' calculation & best 3 years & best 5 years & best 3 years & \\
\hline Special qualifying conditions & & employment must cease & & employment must cease \\
\hline minimum of monthly pension in US \$ & 148 & 111 & 104 & 470 \\
\hline maximum of monthly pension in US \$ & $60 \%$ of average covered earnings up to 1444 & $60 \%$ of average covered earnings & $60 \%$ of average covered earnings & \\
\hline \multicolumn{5}{|l|}{ benefit adjustment } \\
\hline Payable abroad & no & yes & & yes \\
\hline old age /retirement pension & $\begin{array}{l}30 \% \text { of the insured's average earnings plus } 2 \% \text { for } \\
\text { each } 50 \text { week period of contributions exceeding } \\
500 \text { weeks up to } 799 \text { weeks, plus } 1 \% \text { for each } 50 \text { - } \\
\text { weeks exceeding } 799 \text { weeks }\end{array}$ & $\begin{array}{l}40 \% \text { of the insured's monthly average earnings } \\
\text { plus } 0,1 \% \text { for each month of contributions } \\
\text { exceeding } 180 \text { months }\end{array}$ & $\begin{array}{c}16 \% \text { of the insured's average earnings plus } 1 \% \text { for } \\
\text { each } 25 \text { week period of contributions exceeding } \\
150 \text { weeks up to } 500 \text { weeks, plus } 0,5 \% \text { for each } 25 \\
\text { weeks exceeding } 500 \text { weeks }\end{array}$ & $\begin{array}{l}30 \% \text { to } 48 \% \text { of the average of weekly earnings } \\
\text { plus } 0,56 \% \text { to } 0,71 \% \text { according to } 16 \text { wage classes } \\
\text { for each } 25 \text {-week period of contributions } \\
\text { exceeding } 750 \text { weeks }\end{array}$ \\
\hline Deferral pensions & & only up to age 65 & & \\
\hline Early pensions & & minus $0,5 \%$ for each month before pensionble age & & \\
\hline old age settlement (in US\$) & $\begin{array}{c}\text { the contributions are refunded if less than } 50 \\
\text { weeks of contributions }\end{array}$ & & & three times of the total the contributions paid \\
\hline \multicolumn{5}{|l|}{ Social assistance programs } \\
\hline old age grant & $\begin{array}{l}\text { a lump sum of six times of average covered } \\
\text { earnings for each } 50 \text {-week periods of paid or } \\
\text { credited contributions up to } 499\end{array}$ & $\begin{array}{l}100 \% \text { of balance of the provident fund plus } \\
\text { accrued interest and } 0,67 \% \text { of yearly average } \\
\text { covered earnings for each month of cntributions } \\
\text { after March } 1979\end{array}$ & $\begin{array}{l}\text { a lump sum of six times of average covered } \\
\text { earnings for each } 50 \text {-week periods of } \\
\text { contributions }\end{array}$ & \\
\hline minimum of old age grant in US\$ & & & & 470 \\
\hline non-contibutory old age pension (monthly, in US\$̦) & 93 & & & up to 470 \\
\hline
\end{tabular}

\section{REFERENCES}

[1] (1952) Social Security Minimum Standards Conventions (ILO)

[2] (2000) E.Huber, J.D. Stephens: The Political Economy of Pension Reform: Latin America in Comparative Perspective (UNRISD, Geneva)

[3] (2001) P.Plamondon - D.Osborn : Social Security financing and investments in the Caribbean _ Report of the Caribbean Sub-Regional Tripartite Meeting on Social Security: (Bridgetown, Barbados, 24-25 October 2001)

[4] (2002) Strengthening the "social" in Social Security, Annual Report, National Insurance Corporation, Saint Lucia

[5] (2003) Regional Strategy for Implementation in Latin America and the Caribean of the Madrid International Plan of Action On Aging, ECLAC Regional Intergovernmental Conference on Ageing, Santiago, Chile

[6] (2004) D.Osborn: Social Security in the CARICOM Single Market and Economy, CaricomSecreteriat

[7] (2004) R.tenWolde: Pan-European Pension Institutions: From Concept to Prototype (Benefits \& Compensation International • JUNE 2004)

[8] (2005)A Quarter Century of Pension Reform in Latin America and the Caribbean. (Ed.Carolin A. Crabbe) Inter-American Development Bank

[9] (2005) Antigua and Barbuda, Social Protection Assessment, Staff Country Report, IMF

[10] (2005) Migration in the Caribbean -What do we Know? , ECLAC, Port of Spain, Trinidad and Tobago

[11] (2007) O. Paddison: Social protection in the English-speaking Caribbean, CEPAL Review 92

[12] (2008) D.R. Brown: Institutional Development and Reform in Public Services : Lessons from the experience of Small Caribbean States, CAPAM. BIENNIAL CONFERENCE, Barbados

[13] (2008) D.R. Brown: Institutional Development and Reform in Public Services : Lessons from the experience of Small Caribbean States, CAPAM. BIENNIAL CONFERENCE, Barbados

[14] (2009) STRENGTHENING CARIBBEAN PENSIONS: IMPROVING EQUITY AND SUSTAINABILITY ( World Bank, LATIN AMERICA AND THE CARIBBEAN REGION HUMAN DEVELOPMENT GROUP, Report No. 47673-LAC)

[15] (2009) G.Miller : In Search of a Fair Pension Formula - Realistic income-replacement ratios in the 'new normal' economy (Governing)

[16] (2009) F. Alleyne: The Future of Social Security in the English-speaking Caribbean, Barbados

[17] (2009) G.Miller : In Search of a Fair Pension Formula - Realistic income-replacement ratios in the 'new normal' economy (Governing)

[18] (2010) Social Security in CARICOM, CARICOM Secreteriat, Barbados 
[19] (2010) Barbados and Eastern Caribbean - Crisis Poverty and Social Impact Analysis (PSIA, The Inclusive Development Cluster, Poverty Group, February 2010)

[20] (2010) A.Fortesa: The Portability of Pension Rights: General Principles and the Caribbean Case (Development Policy Review, 2010, 28 (2): 237-255)

[21] (2011) Dr. Anthony Birchwood : Harmonisation of pension reforms in Caricom (Caribbean Centre for Money and Finance, Newsletter, Vol.5.No11.

[22] (2011) M.St Rose: Recommendations from the ECCU Pension Reform Commission (Presentation for Caribbean Actuarial Association )

[23] (2011) Assessment of Social Security Organisations and Possible Harmonisation of Qualifying Conditions for Improved Policy Environment to facilitate Free Movement (Final report by Callund Consulting, CARICOM: CISP/CSME/1.5.1.5/SER09.10) 2011

[24] (2011) Eastern Caribbean Currency Union : Selected Issues , MF (Staff Country Reports,

[25] (2011) M.Ayuso- D. Valero: Can complementary pension plans take on the role of improving retirement pensions in developing nations? Case Study - The Dominican Republic, RISC-IREA, Avda. Diagonal, 690, 08034 Barcelona

[26] (2011) An Agenda for Adequate, Safe and Sustainable Pensions (White Paper, European Commission)

[27] (2011) A. Forteza: ANTIGUA and BARBUDA ,Social Protection Assessment (WB)

[28] (2012) D. Osborn: The Recent Economic Crisis Wasn't All Bad For Caribbean Social Security Schemes (presentation ont he ISSA Conference, Berlin)

[29] (2012) A. Birchwood: HARMONISATION OF PENSION REFORMS IN CARICOM, (Caribbean Centre for Money and Finance, Newsletter, Volume 5)

[30] (2012) World Population Prospects: United Nations, Department of Economic and Social Affairs, Total population (both sexes combined) by five-year age group, major area, region and country, 1950-2100 (thousands)

[31] (2013) Synopsis of the English-Speaking Caribbean Social Security Systems (2013, Inter-American Centre for Social Security Studies (CIESS)) (by H. P. Montas)

[32] (2013): Social Security Programs Throughout the World,: The Americas , Official Social Security website of US Government

[33] (2013) Social Security in the English-speaking Caribbean (UN, 2006, ISBN 9789211215953) Economic Commission for Latin America and the Caribbean

[34] (2013) M. Richardson: Determinants of Social Security Compliance in a Small Island Developing States. An analysis of Anguilla, Central Bank of Barbados, Working Paper No. WP/13/12)

[35] (2013) R.Holzman- E. Palmer-D.Robalino (editors): Nonfinancial Defined Contribution Pension schemes in a Changing Pension World (World Bank)

[36] (2013) M.Lavigne-L.H Vargas: Social protection systems in Latin America and the Caribbean: Jamaica, UN ECLAC

[37] (2013) H. P.ontas: Synopsis of the English-Speaking Caribbean Social Security Systems(Inter-American Center for Social Security Studies (CIESS)

[38] (2013) Saint Lucia's National Social Protection, Eastern Caribbean Social Protection Newsletter,No5 UNICEF

[39] (2014) World Development Indicators (ILO)

[40] (2014) D. Quarless: Experiences on Human Rights for Older Persons: a Caribbean Perspective Second International Forum on the Human Rights of Older Persons, Mexico City)

[41] (2014)Seminar in the Anglo-Caribbean Region on Social Security and Universal Health Coverage, Roseau, Dominica

[42] (2014) (Un)reforming pension system (ERSTE Group Research, Poland )

[43] (2014) J. M. Poterba: Retirement Security in an Aging Population (American Economic Review, 104(5): $1-30$

[44] (2014)G. Bernardino: Towards a EU single market for personal pensions, (EIOPA Public Event on Personal Pensions, Bratislava)

[45] (2014) Actuarial Methods and Assumptions used in the Valuation of Retirement Benefits in the EU and other European Countries (EAA)

[46] (2014) Pensions in Europe - How multinational companies are preparing their pensions in Europe for the future, The AEGON Global Pensions European Pensions Survey (2011)

[47] (2014) P.Scommegna and M. Lee:Aging in Latin America and the Caribbean, Population Reference Bureau, US 
[48] (2015) L. Blows: The Need for Reforms (European Pensions, January)

[49] (2015) G. Osborn: Pension reforms in the UK: what can be learned from other countries? (Oxera Agenda, January)

[50] (2015) World Economic Situation and Prospects, World Bank Publication

[51] EUEEA Pension Statistics 2004-2013

[52] CARICOM Statistics (web-pages)

[53] ASSESSMENT REPORT ON THE DEVELOPMENT AND STRENGTHENING THE CSME SOCIAL SECURITY REGIME AND RECOMMENDED AMENDMENTS TO THE CARICOM AGREEMENT ON SOCIAL SECURITY for the CARICOM Secretariat CSME Unit ( as part of the project titled Establishment of a labour information system for proper management of the regime for free movement of skills within the CSME ) (Project paper, 2015)

\section{AUTHOR'S BiOgRAPHY}

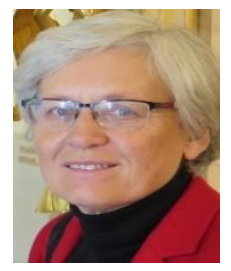

Agnes Matits, economist, actuary (1991 Karl Marx University of Economics, Budapest and 2002 Corvinus University Budapest). Partner and Managing actuary in Matits@Török Consulting Ltd. Hon. Senior lecturer of Corvinus University Budapest Previous activities: 1971-1989 lecturer ( Department of Mathematics, Univ. Economics, Budapest ) 1991-2007 senior advisor (International Training Center for Bankers, Budapest ) Pension specialist ( W.M.Mercer Budapest 1993-0995) . Actuarial consultant at several private pension funds (1993-2010). She is a funding member of the Hungarian Actuarial Society and delegated member in the Pension Commettee of Actuarial Assotiation of Europe (until 2017).

Citation: Agnes Matits. "Social Security Systems in the CARICOM Member States". International Journal of Humanities Social Sciences and Education (IJHSSE), vol 5, no.11, 2018, pp. 43-62. doi: http://dx.doi.org/10.20431/2349-0381.0511006.

Copyright: (C) 2018 Authors. This is an open-access article distributed under the terms of the Creative Commons Attribution License, which permits unrestricted use, distribution, and reproduction in any medium, provided the original author and source are credited. 